


\title{
Employment vs. homestay and the happiness of women in the South \\ Caucasus
}

\author{
Karine Torosyan \\ International School of Economics at TSU, and Global Labor Organization \\ Norberto Pignatti \\ International School of Economics at TSU, Human Capital and Economic Opportunity Working \\ Group and IZA Institute of Labor Economics
}

\begin{abstract}
Modern women often face an uneasy choice: dedicating their time to reproductive household work, or joining the workforce and spending time away from home and household duties. Both choices are associated with benefits, as well as non-trivial costs, and necessarily involve some trade-offs, influencing the general feeling of happiness women experience given their decision. The trade-offs are especially pronounced in traditional developing countries, where both the pressure for women to stay at home and the need to earn additional income are strong, making the choice even more controversial. To understand the implications of this choice on the happiness of women in these types of countries we compare housewives and working women of the South Caucasus region. The rich data collected annually by the Caucasus Research Resource Center allows us to match working women with their housewife counterparts and to compare the level of happiness across the two groups - separately for each country as well as for Armenian and Azerbaijani minorities residing in Georgia. We find a significant negative happiness gap for working women in Armenia and in Azerbaijan, but not in Georgia. The absence of such a gap among the Armenian and Azerbaijani minorities of Georgia indicates that the gap is mostly a country- rather than an ethnicity-specific effect.
\end{abstract}

JEL Classification: I31, J16, J21, J24

Keywords: Female employment, reproductive housework, life satisfaction and happiness, propensity score matching.

\section{Corresponding author:}

Karine Torosyan

International School of Economics

Tbilisi State University

Zandukeli Street 16

0108 Tbilisi

Georgia

Email address: k.torosyan@iset.ge 


\section{Introduction}

Happiness is an important measure of welfare and its pursuit is one of the strongest driving forces behind all human activities. The rapidly developing field of happiness economics aims at complementing income-based measures of welfare, which are widespread in the economic literature, with self-reported levels of happiness, measured on the ordinal scale. While these measures are undoubtedly subjective, self-reported happiness has proved to be a good proxy for "objective" happiness. Psychologists have showed that this measure of happiness is associated with consistent patterns of pre-frontal cortex activity, heart rate, digestive disorders, headaches, etc. (Graham, 2005; Brodeur and Connolly, 2012).

Our paper focuses on the intriguing topic of working outside of the home and its significance for women's self-reported happiness. This topic is not new, and has been the subject of wide scholarly interest for several decades. However, research has not clearly resolved whether the relationship between women's happiness and employment is positive or negative. This indeterminacy mostly stems from the complicated interplay of factors that impact women's happiness in each of the states (employment or homestay). Some of these factors capture individual and family characteristics, while others are contextual in nature and reflect formal and informal patterns that guide social interactions. The relative importance of these factors for the happiness of women depending on their employment status varies greatly across countries and cultures, as well as over time, ensuring that the question remains pertinent over time. Given the great variation among countries in terms of formal and informal institutions, cultural norms and population characteristics, it is especially important to study the contribution of the different country-specific factors to women's happiness. This can greatly assist in designing more targeted policies that can successfully minimize women's costs and ensure that the decision to enter the labor market is as "happiness-enhancing" as possible.

In this paper we expand on the existing literature on the topic in several important dimensions. Firstly, we study the previously unexplored geographic and cultural setting of the countries of the South Caucasus, including Armenia, Azerbaijan, and Georgia. All three countries of interest are former republics of the USSR, are small developing countries on the Europe-Asia divide, and have strong traditional values and a strict division of gender roles. Given that the existing literature on the topic concentrates heavily on developed countries, with only a few examples that deviate from this trend, our study of the South Caucasus region offers a valuable extension to the previously explored "map" underlying the question of women's happiness and their employment status. Secondly, we

offer new evidence on the impact of country characteristics versus ethnicity/cultural factors on the happiness of women with different employment statuses. In so doing, we exploit the substantial presence of Azerbaijani and Armenian minorities in Georgia to explore the extent to which the differences across countries can be attributed to different ethnic/cultural factors rather than to 
differences in existing country-specific settings, such as formal institutions and policies. Finally, we address the issue of favoring the middle value by respondents when they have to choose their happiness ranking on a limited scale (1 to 10 in our case), by examining the tails of the happiness distribution. More specifically, in addition to estimating the mean happiness gap, we build two additional outcome variables: very unhappy (aggregating happiness levels 1-3) and very happy (aggregating happiness levels 8-10) and estimate the difference in probability of being very (un)happy across working women and housewives.

Our findings suggest that there is a significant negative happiness gap for working women in Armenia, and a less pronounced negative gap for working women in Azerbaijan, but there is no difference in happiness level for women in Georgia. In addition, we find that working women in Armenia, and to some degree in Azerbaijan, are less likely to attain the highest levels of happiness compared to their housewife counterparts: the upper tail of happiness distribution for working women in these two countries is thinner than that of comparable housewives. No such effect is observed in Georgia.

Interestingly, we do not observe a negative happiness gap for working women of Armenian and Azerbaijani ethnicity living within Georgia, indicating that the gap is mostly due to country specific characteristics and not so much to ethnic/cultural factors. This finding suggests that it is possible to tip the happiness scale in favor of working women through adjusting formal policies and regulations, and that cultural/ethnic factors, which are often rather inert, play a secondary role in this case.

The rest of the paper is structured in the following way. In the next section we briefly review the most relevant literature on the topic. We then discuss the attitudes towards gender roles and the challenges faced by women balancing work and family in the three countries under consideration. Next, we describe the data and the methodology used in the analysis. The discussion of results, their robustness, and a summary of the main findings conclude the paper.

\section{Review of the literature}

The last several decades have been characterized by a notable increase in the labor force participation of women at the world level (World Bank, 2011). As women's labor force participation increased, more women could pursue successful careers and get better paid and more prestigious jobs (Blau et al., 2006). While at first sight this trend suggests an clear improvement in women's well-being and happiness due to a number of benefits stemming from employment, a deeper investigation into the issue reveals several downsides that women face when they get into employment.

The literature documents a wide range of direct and indirect benefits stemming from women's paid work. Employment increases the economic resources at the disposal of the working woman and her 
family, leading to increased well-being (Ball and Chernova, 2008; Mentzakis and Moro, 2009) and marital happiness (Rogers and DeBoer, 2001). Besides providing monetary rewards, employment expands a woman's social networks (Behtoui, 2007; Greenhaus and Powell, 2006) and allows her to achieve a deeper feeling of personal fulfillment and social appreciation (Mueller and Kim, 2008).

In addition to these direct positive effects, some of the beneficial indirect effects of female employment include enrichment of family experience due to improved mood from employment (Stevens et al., 2007), better bargaining positions within the family over housework (England and Farkas, 1986; Majlesi, 2016) and expenditures (Beblo and Beninger, 2017; Dasgupta and Mani, 2015), lower risk of domestic physical violence (including sexual violence) and emotional abuse in more egalitarian couples (Lenze and Klasen, 2017; Oduro et al., 2015; Alonso-Borrego and Carrasco, 2017).

However, increased female labor force participation comes with many non-negligible costs. When a woman enters the labor market, her household has to find an alternative way to ensure that all the household-related activities she was performing - housework, childcare and elderly care, to cite the most common ones - are taken care of. This depends on how easy it is to shift some of these tasks to other individuals and/or to social support systems. If these responsibilities cannot be outsourced, women end up working a "second shift", as Arlie Hochschild defined it in 1989, and have to work longer hours with higher intensity in order to manage their tasks both within and outside of the home. Physical and psychological stress resulting from this dual burden can translate into high personal costs and lower happiness (Van der Lippe and Peters, 2007; Nomaguchi et al., 2005; Baxter and Tai, 2016).

The increased burden on working women is likely to be especially heavy in the most traditional societies, where gender roles are deeply rooted. This is, for example, the case in the South Caucasus, where traditional values are still strong and the division of housework and care responsibilities among spouses is quite unequal (Torosyan et al., 2015). Often in those same societies paid work is more of a need than a choice for women due to difficult economic conditions. For instance, Pastore and Vereshchagina (2011) argue that - in the Belorussian case - female labor force participation is kept high because of the need to support household income, despite large and growing gender wage gaps. Along the same lines, Khitarishvili (2013) finds evidence of the existence of an "added worker effect" ${ }^{\prime \prime}$ in transition economies following the 2008 economic crisis. This saw a reduction in male employment, followed by an increase in female labor market participation, especially in weak labor market environments. Women's employment may become less necessary as societies build stronger financial buffers, such as personal savings and efficient financial markets (Bohnke, 2005; Easterlin,

\footnotetext{
${ }^{1}$ We speak of the added worker effect when a negative shock hitting the household pushes a previously non-working household member (most likely women) into the labor market.
} 
1973) and develop effective welfare policies (Clarke et al., 2004), which can help mitigate the impact of temporary economic shocks on families.

In addition, the social depiction of women in a given society impacts the behavior of individuals and the way they feel (Kuperberg and Stone, 2008; Treas and Widmer, 2000; Tesch-Romer et al., 2008). Public opinion can be rather negative about a married woman's paid work, particularly full-time work, and especially in families with young children (Charles and Cech, 2010; Tres and Widmer, 2000). As a result, working women often report feeling guilty for spending time away from "woman's" duties and for being "bad" mothers and wives (Guendouzi, 2006), while housewives enjoy the feeling of satisfaction that comes from fulfilling traditional gender roles (Crompton and Lyonette, 2005). Negative feelings and perceptions associated with women's employment might translate into having a negative effect on marital satisfaction (Allen et al., 2000) and marriage stability, especially if the men's contribution to unpaid work is limited (Mencarini and Vignoli, 2018).

Based on the discussion above, it is not obvious that entering the labor market would always lead to an increase in women's happiness. Indeed, there is no consensus in the literature about the impact of employment on women's well-being. Multiple studies (both cross-sectional and longitudinal) on this topic in the case of the US report that there are positive, negative, or no differences in the wellbeing of working women compared to that of housewives (Campbell, 1981; Schoen et al., 2006; Stevenson and Wolfers, 2009). Australian women going into full-time employment show a decline in life satisfaction (Booth and van Ours, 2009), while Indian working wives seem to be happier compared to the housewives (Nathawat and Mathur, 1992). A recent study of four East Asian countries with traditional gender relations finds that full-time employment is negatively associated with women's happiness in Japan, but no such effect is documented in the cases of China, South Korea and Taiwan (Hori and Kamo, 2017). These are only a few examples highlighting the variation in findings from the vast literature on individual countries at different points in time.

A number of cross-country studies investigate how happiness differences between housewives and working wives depend on cultural and social contexts. One study shows that, while in Eastern Europe full-time work is superior to being a housewife, in Asia self-employment brings more happiness to women (Beja, 2012). Another interesting cross-country study of homemakers and working women finds that homemakers are a little happier than full-time working women and that country characteristics - such as GDP, social spending, women's labor force participation, liberal gender ideology and public child care - ameliorate the disadvantage in happiness for full-time working wives (Treas et al., 2011). 
When it comes to the geographic coverage of the literature on the topic, the area of post-transition countries is poorly explored in the previous research. In fact, to our knowledge, our study is the first to compare the happiness of working women and housewives in the post-USSR area. We believe that this region is very different in nature from both developed and developing countries due to its unique historical past and the current state of transition, and it thus deserves special attention. In our study we focus on women in two states - those that are working and housewives. We are not distinguishing between the sector of employment (i.e. the public sector, self-employment, private sector) and are pulling together full- and part-time employment. It is true that there is a welldocumented positive gap in happiness for women in part-time employment compared to both housewives and fully employed women (Booth and van Ours, 2008, 2009, 2010; Treas et al., 2011; Beja, 2012), and some studies find that self-employed wives are more satisfied with life compared to their counterparts in non-employment and full-time employment (Blanchflower and Oswald, 1998), but we are unable to observe these differences across sectors and employment statuses due to data limitations.

\section{Country backgrounds}

Armenia, Azerbaijan and Georgia were part of the Soviet Union for more than 70 years. During this period, they shared political, economic and social institutions. When the Soviet Union collapsed in 1991, each country followed its own path, re-asserting some of its own specificities. Nowadays, the countries of the South Caucasus are still quite similar in many aspects, but are also characterized by a number of differences that are relevant to our study as they might affect the level of happiness of housewives and employed women in different ways.

The data collected by the World Values Survey ${ }^{2}$ for the years 2010-2014 (covering a similar timespan as the data we are analyzing in sections below) generate a strong impression that South Caucasus countries are still quite traditional, with Georgia being relatively closer to more egalitarian European countries and Azerbaijan being the furthest away from those (Table 1).

Both family and work are very important in the South Caucasus region countries compared to the other FSU and EU countries captured in the survey. All three countries find family to be extremely important, with Armenian and Georgian respondents almost uniformly ranking it as such. The importance of work was indicated by two out of three respondents in Azerbaijan, and that share rises to three out of four in Georgia and Armenia. In comparison, only half of respondents from EU countries prioritized work as being important. Considering the relatively underdeveloped system of social safety nets in the South Caucasus countries compared to those in most European countries,

\footnotetext{
${ }^{2}$ For details see: http://www.worldvaluessurvey.org/WVSContents.jsp
} 
the reliance of families on labor income and hence the importance of work in this region is understandably high.

Table 1: Summary of opinions based on the World Values Survey (WVS), 2010-2014

\begin{tabular}{|l|c|c|c|c|c|}
\hline \multicolumn{1}{|c|}{ WVS Question (\% agree) } & Az & Arm & Geo & FSU & EU \\
\hline Family is very important in my life & 0.94 & 0.97 & 0.98 & 0.92 & 0.89 \\
\hline Work is very important in my life & 0.67 & 0.71 & 0.73 & 0.57 & 0.51 \\
\hline When jobs are scarce men have more rights to jobs than women & 0.79 & 0.56 & 0.46 & 0.39 & 0.18 \\
\hline A job is the best way for women to be independent & 0.33 & 0.45 & 0.65 & 0.51 & 0.63 \\
\hline Being a housewife is just as fulfilling as working for pay & 0.70 & 0.52 & 0.50 & 0.85 & 0.48 \\
\hline It is a problem if women have more income than their husbands & 0.38 & 0.39 & 0.26 & 0.30 & 0.17 \\
\hline When a mother works for pay, the children suffer & 0.50 & 0.54 & 0.65 & 0.37 & 0.32 \\
\hline
\end{tabular}

Source: World Values Survey, Wave 6.

Notes: Az, Arm and Geo stand for Armenia, Azerbaijan and Georgia respectively; the FSU group includes six Former Soviet Union Countries (excluding Armenia, Azerbaijan and Georgia); the EU group includes nine countries of the European Union; see Table A1 in the Appendix for country lists. Year of data collection: Azerbaijan - 2011, Armenia - 2011, Georgia - 2014, FSU and EU - 2011-2014.

From responses to the question "When jobs are scarce, men should have more rights to jobs than women" it is clear that in the South Caucasus countries there is a gender gap in terms of the perceived right to having a job. This gap is especially pronounced in Azerbaijan, where almost $80 \%$ of respondents agree with this statement. This share goes down to 56\% in Armenia and 46\% in Georgia, but remains very high. In comparison, less than $20 \%$ of European respondents agreed with this statement.

In Azerbaijan, employment is not commonly viewed as the best way for women to be independent, while being a housewife in this country is generally considered to be just as fulfilling as working for pay. Instead, in Georgia a much larger share of respondents sees employment as a liberating activity for women and a smaller share considers housewifery as fulfilling as working for pay. Indeed, Georgian responses to these two questions are almost identical to those of respondents from the EU countries. Armenia holds the middle position between the other two countries of the South Caucasus region.

There is higher sensitivity in the South Caucasus, and especially in Armenia and Azerbaijan, to women earning more income than their husbands compared to the EU. This sensitivity stems from the fact that men in the South Caucasus region have traditionally been the (main) breadwinners in the family, and the ability to fulfill this role remains very important in contemporary settings.

Our final observation based on the WVS data is that respondents from all South Caucasus countries, and especially from Georgia, are very concerned about the wellbeing of their children when mothers work for pay. Two out of three respondents in Georgia and every second respondent in Armenia and 
Azerbaijan are alarmed about the issue of working mothers and its impact on the wellbeing of children. In comparison, only one out of three Europeans expressed similar concerns.

Next, we turn to labor market-related indicators for the three countries of the South Caucasus. We obtain these from the World Development Indicators (WDI) and from the International Labor Organization (ILO) databases (Table 2). To see the evolution of the indicators over time, we report data for 2010, 2013 and 2017; for comparison we also present aggregate data for FSU and EU countries.

In the South Caucasus countries a large share of employment is classified as being vulnerable, with women characterized as having an especially high incidence of vulnerable employment $(62 \%$ in Azerbaijan, 46\% in Armenia and 55\% in Georgia). The share of vulnerable employment is much lower in other FSU countries and in the EU, with the share of vulnerable employment among women being the lowest in the latter $(10 \%)$.

The possibility of engaging in part-time work is a crucial element in a strategy aimed at a better work-life balance. Part-time work allows women to free up more time that can be used to cope with housework and caring responsibilities, reducing friction, stress and overwork. Table 2 summarizes statistics on the prevalence of part-time employment in the countries of our interest. Almost half of female employment in EU countries is of a part-time nature - this is a very high share, signaling a high level of job market flexibility for women in this region. The share of men in the EU with parttime jobs is much lower and comprises $13-14 \%$ of total male employment. Interestingly, the share of women in part-time employment in Armenia and Georgia is not very different from that in the EU. However, data for Armenia suggest that part-time job opportunities are declining over time (data for Georgia is missing, so we do not know if a similar trend is true for Georgia). In contrast, part-time employment for women is much lower in Azerbaijan and other FSU countries, where only a quarter of female employment is classified as part-time.

The last labor market indicator we present in Table 2 is the average monthly remuneration for labor (reported in current USD). The level of compensation for paid work in the South Caucasus and other FSU countries is much lower compared to that in EU countries, and has declined in the South Caucasus region towards the end of the period under consideration. The job market in our three countries of interest thus does not seem to be particularly rewarding, even compared to other FSU countries. What is even more worrisome is that there is a wider gender gap in wages characteristic to the South Caucasus countries. Table 3 below shows gender gap statistics calculated based on the data from Table 2. Here we can see an interesting distribution of values ranging from the lowest of about $20 \%$ in EU countries to the highest of 50\% in Azerbaijan. In conclusion, labor remuneration 
is relatively low in the South Caucasus countries in general, and is particularly low for women in this region.

Table 2: Selective labor market statistics from World Development Indicators, by gender

\begin{tabular}{|c|c|c|c|c|c|c|c|c|c|c|}
\hline \multirow[b]{2}{*}{ Variable/year } & \multicolumn{2}{|c|}{$\mathbf{A z}$} & \multicolumn{2}{|c|}{ Arm } & \multicolumn{2}{|c|}{ Geo } & \multicolumn{2}{|c|}{ FSU } & \multicolumn{2}{|c|}{ EUU } \\
\hline & $\mathbf{F}$ & M & $\mathbf{F}$ & M & $\mathbf{F}$ & $\mathbf{M}$ & $\mathbf{F}$ & $\mathbf{M}$ & $\mathbf{F}$ & M \\
\hline \multicolumn{11}{|c|}{ Vulnerable employment (percent of total employment) } \\
\hline 2010 & 62.2 & 50.2 & 49.7 & 37.0 & 57.5 & 57.4 & 22.4 & 23.0 & 10.2 & 23.9 \\
\hline 2013 & 62.1 & 51.1 & 48.0 & 37.5 & 56.6 & 55.6 & 22.7 & 23.8 & 9.8 & 25.6 \\
\hline 2017 & 62.2 & 48.7 & 40.1 & 40.8 & 50.1 & 49.2 & 19.0 & 21.9 & 9.2 & 25.1 \\
\hline \multicolumn{11}{|c|}{ Part-time employment (percent of total employment) } \\
\hline 2010 & 28.5 & 19.2 & 54.3 & 30.1 & .. & & 24.8 & 17.0 & 47.1 & 14.1 \\
\hline 2013 & 22.9 & 14.3 & 46.3 & 25.9 & 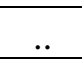 & & 25.4 & 16.5 & 48.5 & 14.1 \\
\hline 2017 & 23.7 & 14.4 & 42.9 & 23.9 & 46.8 & 33.6 & 25.0 & 13.2 & 47.7 & 13.3 \\
\hline \multicolumn{11}{|c|}{ Mean monthly earnings (current USD) } \\
\hline 2010 & 282 & 515 & 214 & 334 & 240 & 417 & 416 & 630 & 1949 & 2369 \\
\hline 2013 & 331 & 697 & 279 & 425 & 352 & 554 & 381 & 535 & 2188 & 2783 \\
\hline 2017 & 196 & 388 & &.. & 307 & 477 & 385 & 531 & 2003 & 2600 \\
\hline
\end{tabular}

Source: World Development Indicators and International Labor Organization.

Notes: Vulnerable employment and part-time employment data are from the WDI database. Vulnerable employment is the contributing family workers and own-account workers as a percentage of total employment. Part-time employment refers to regular employment in which working time is substantially less than normal; definitions of part-time employment differ by country. Mean monthly earnings are based on ILO data on the mean nominal monthly earnings of employees by sex, converted to current USD for comparison. The FSU column reports the average data for the same six countries used in Table 1 (based on available data); the EU definition follows that of the WDI and aggregates available data from $28 \mathrm{EU}$ countries.

Table 3: Gender wage gap

\begin{tabular}{|r|c|c|c|c|c|}
\hline \multicolumn{1}{|c|}{ Gender wage gap } & Az & Arm & Geo & FSU & EU \\
\hline $\mathbf{2 0 1 0}$ & 0.45 & 0.36 & 0.42 & 0.34 & 0.18 \\
\hline $\mathbf{2 0 1 3}$ & 0.53 & 0.34 & 0.36 & 0.29 & 0.21 \\
\hline $\mathbf{2 0 1 7}$ & 0.49 &.. & 0.36 & 0.27 & 0.23 \\
\hline Average & 0.49 & 0.35 & 0.38 & 0.30 & 0.21 \\
\hline
\end{tabular}

Source: Own calculations based on data in Table 2

As Table 1 suggests, the concern over the wellbeing of children of working mothers is very high in the South Caucasus. The availability and quality of organized care for young children might thus be a significant factor in our discussion. Table 4 provides statistics on two relevant indicators with respect to the availability of quality care for young children: the gross enrolment ratio in pre-primary education and the pupil-teacher ratio at the pre-primary level of education.

We start our comparison of country statistics by highlighting the very high and steadily increasing (almost reaching full) pre-primary enrollment that is characteristic of EU countries. This increased enrollment is combined with an increased number of teachers engaged in pre-primary education, as is evident from the low and further decreasing pupil-teacher ratio. Enrollment rates in FSU countries 
are a bit lower compared to the EU but are still at a high level (around 80\%), while the pupil-teacher ratio is nearly identical to that in the EU. In terms of the South Caucasus countries, Georgia is the closest to the EU (and FSU) standards, with high and growing enrollment, reaching 70\% towards 2017; Armenia reaches 50\% enrollment with a falling pupil-teacher ratio; and Azerbaijan is the furthest from those standards with an enrollment ratio as low as 25\% for 2010-2013 and reaching $36 \%$ in 2017; however, the latter appears to have occurred at the "expense" of an increased pupilteacher ratio, and thus of reduced quality of care. These data suggest that Georgian, and to some extent Armenian, working women with young children could count on a more developed formal child support system during the period under analysis, whereas women in Azerbaijan have to rely more on informal support or struggle to take care of their childcare responsibilities. However, as the example of FSU and EU countries shows, there is clear room for improvement in the pre-primary education enrollment rates in all three countries.

Table 4: Pre-primary education indicators

\begin{tabular}{|l|c|c|c|c|c|}
\hline Variable/year & Az & Arm & Geo & FSU & EU \\
\hline School enrollment, pre-primary (\% gross) \\
\hline $\mathbf{2 0 1 0}$ & 25.6 & 37.0 & 58.0 & 78.2 & 93.1 \\
\hline $\mathbf{2 0 1 3}$ & 25.7 & 49.8 &.. & 84.5 & 94.1 \\
\hline $\mathbf{2 0 1 7}$ & 36.0 & 52.0 & 69.5 & 79.9 & 96.2 \\
\hline Pupil-teacher ratio, pre-primary \\
\hline $\mathbf{2 0 1 0}$ & 9.3 & 9.8 &.. & 13.8 & 13.2 \\
\hline $\mathbf{2 0 1 3}$ & 10.0 & 8.6 &.. & 13.5 & 12.7 \\
\hline $\mathbf{2 0 1 7}$ & 15.2 & 8.4 &.. & 12.4 & 12.7 \\
\hline
\end{tabular}

Source: World Development Indicators and International Labor Organization.

Notes: The Az, Arm, and Geo columns report data for Azerbaijan, Armenia, and Georgia respectively. The FSU column reports average data for the same six countries used in Table 1 (based on available data); the EU definition follows that of WDI and aggregates available data from $28 \mathrm{EU}$ countries.

We conclude this section by once more highlighting very robust ranking between the three countries of the South Caucasus in various indicators, with Georgia toping the ranking and, in some cases, approaching the level of the EU, Armenia being in the middle, followed by Azerbaijan, which holds the lowest position with respect to most of the parameters we have discussed.

\section{Data and Methodology}

Empirical analysis in this paper is based on the data from the annual surveys conducted by the Caucasus Research Resource Center (CRRC) in all three countries of the South Caucasus region. This data collection initiative (referred to as the "Caucasus Barometer", or CB) started in 2004 with the goal of providing rich, nationally representative, comparable across the countries and a database for researchers and policy makers interested in analyzing data on socio-economic, political, cultural, and other topical issues in the South Caucasus region. Until 2013 the data were collected annually, and afterwards on a biannual basis (2015 and 2017 were the latest years of the survey) for Georgia 
and Armenia, but not Azerbaijan. Data from the CB surveys are publicly available through the CRRC website. ${ }^{3}$

The fieldwork for CB surveys takes place in the November-December period in all three countries of the region following the same methodology. The target population is all adult residents (18 years and older) in each country, with the exception of residents in conflict-affected regions and/or occupied territories (Abkhazia, South Ossetia, and Nagorno Karabagh). The sampling methodology is based on dividing the target population into three "macro-strata" by settlement type: capital, urban and rural. Within each stratum, PSUs (primary sampling units, which are electoral precincts) are sampled with a probability proportional to the number of registered voters in each stratum. To obtain a sampling frame within each PSU, a block listing procedure is used (which is listing/updating an earlier created list of households actually living in each PSU). Finally, PSU lists are used to randomly sample households to be interviewed. The size of the sample in each country for each year is approximately 2,000 respondents.

The CB surveys ask a wide variety of questions, aiming at collecting detailed data about the respondent. Questions range from those focused on personal characteristics (gender, age, education, ethnicity, religion, etc.) to various opinion and perception questions (including questions about perceived economic rank, trust level, and happiness, to name but a few). In addition, a subset of questions collect data on all household members, from which household composition/structure can be constructed. Finally, there are questions on the economic well-being of the household, its expenditures, and other household descriptors.

Our main outcome variable is the self-reported level of happiness based on the questions: "Overall, how happy would you say you are?" with answer options ranging from 1 (extremely unhappy) to 10 (extremely happy). Even though CB surveys go back to 2004, this question was introduced in 2010, so in our study we make use of data collected from that year onwards.

The main goal of this study is to compare the happiness level for housewives and working women. Table 5 explains how women are categorized into these two groups based on their answers to relevant survey questions.

All categories labeled N/A in Table 5 (students, retired, not employed/not looking for jobs, disabled and other) are excluded from the analysis discussed in the next section. Given our focus on workingage women, we also exclude women aged above 60 years. ${ }^{4}$

\footnotetext{
${ }^{3}$ For more information about the Caucasus Barometer data initiative, see: http://www.crrccenters.org/20119/Project-Overview

4 The official retirement ages for women in the period under discussion is as follows: Azerbaijan - ranges between 57.5 in 2010 and 60 in 2017, averaging 59 years old; Armenia - 63 years; Georgia - 60 years.
} 
Table 5: Definition of "housewife" and "working woman" categories

\begin{tabular}{|c|l|c|c|}
\hline \multicolumn{3}{|c|}{ Which of the following best describes your situation? List the activity/situation which is primary for you. } \\
\hline $\mathbf{1}$ & Retired and not working & N/A \\
\hline $\mathbf{2}$ & Student and not working & N/A \\
\hline $\mathbf{3}$ & Housewife and not working Are you currently interested in a job? & Yes & N/A \\
\cline { 3 - 5 } & & No & Housewife \\
\hline $\mathbf{4}$ & \multirow{2}{*}{ Not employed Are you currently interested in a job? } & No & Housewife \\
\hline $\mathbf{5}$ & Working (part-time or full-time), including seasonal work & N/A \\
\hline $\mathbf{6}$ & Self-employed, including seasonal work & Working \\
\hline $\mathbf{7}$ & Disabled & Working \\
\hline $\mathbf{8}$ & Other & N/A \\
\hline
\end{tabular}

Before proceeding, we want to offer an additional insight into the data. Georgia is an ethnically diverse country ${ }^{5}$ : it is home to several ethnic minorities, Armenian and Azerbaijani being the largest of those groups (based on CB samples, we estimate that $5.4 \%$ of the population in Georgia are ethnic Armenians, and $6.2 \%$ are ethnic Azerbaijani). This diversity of Georgia allows us to split the sample for Georgia into ethnically Georgian and non-Georgian women. This split is interesting because we can compare how ethnic minorities living in Georgia fare against their fellow nationals living in their motherlands, and how they compare to Georgians living in Georgia. This way we can trace "nationality effects" (being more similar to people of the same ethnicity) versus the "country effect" (being more similar to other ethnicities living in the same country).

Table 6 tabulates the initial number of observations for each country/ethnicity for the two categories of interest: housewives (HW) and working women (WK); and for observations dropped from the analysis (category "Dropped"). As we can see, the two categories we focus our attention on are relatively large and together cover between $54-67 \%$ of adult women in the region.

Table 6: Observations by categories (women 18-60 years old, CB 2010-2013/2015/2017)

\begin{tabular}{|l|c|c|c|c|c|c|c|}
\hline \multirow{2}{*}{ Country/Ethnicity } & Total & \multicolumn{2}{|c|}{ HW } & \multicolumn{2}{c|}{ WK } & \multicolumn{2}{c|}{ Dropped } \\
\cline { 2 - 8 } & $\mathbf{N}$ & $\mathbf{N}$ & $\mathbf{\%}$ & $\mathbf{N}$ & $\mathbf{\%}$ & $\mathbf{N}$ & $\mathbf{\%}$ \\
\hline Armenia & 5,119 & 1,410 & $28 \%$ & 1,688 & $33 \%$ & 2,021 & $39 \%$ \\
\hline Azerbaijan & 3,131 & 1,319 & $42 \%$ & 777 & $25 \%$ & 1,035 & $33 \%$ \\
\hline Georgia & 5,556 & 1,227 & $22 \%$ & 1,837 & $33 \%$ & 2,492 & $45 \%$ \\
\hline Georgia/Georgian & 4,784 & 922 & $19 \%$ & 1,657 & $35 \%$ & 2,205 & $46 \%$ \\
\hline Georgia/Armenian & 306 & 113 & $37 \%$ & 80 & $26 \%$ & 113 & $37 \%$ \\
\hline Georgia/Azerbaijani & 339 & 164 & $48 \%$ & 61 & $18 \%$ & 114 & $34 \%$ \\
\hline
\end{tabular}

Source: CB surveys 2010-2017

Notes: HW stands for housewives, and WK for working women.

In our study we are primarily interested in comparing the self-reported happiness level of working age women in the target region with a focus on how working women feel compared to their

\footnotetext{
5 The situation in Armenia and Azerbaijan is very different - both countries are predominantly populated by their own nationals and are home to tiny numbers of ethnic minorities of Russians, Kurds and other Caucasians.
} 
housewife counterparts. For this purpose, after we narrow our sample down to these two groups, we fit a probit regression that helps to explain how the probability of being in either group relates to various characteristics. Based on the probit estimation results, we find women from both groups that are close matches for each other (based on their predicted probability of being in either group) and then compare the average level of happiness across the matched respondents. The first section of the Appendix summarizes technical details behind this methodology and its implementation.

\section{Analysis and Results}

We begin our analysis with a comparison of the reported levels of happiness (our outcome variable) for working women and housewives in all three countries of the region (see Table 7).

Table 7: Average happiness level, by country and working status

\begin{tabular}{|l|c|c|c|c|}
\hline Country/Ethnicity & HW & WK & Diff: WK-HW & t-stat \\
\hline Armenia & 7.14 & 6.73 & $-0.41^{* * *}$ & -4.69 \\
\hline Azerbaijan & 6.33 & 5.99 & $-0.33 * * *$ & -3.51 \\
\hline Georgia & 7.00 & 7.22 & $0.22 * * *$ & 2.67 \\
\hline Georgia/Georgian & 7.28 & 7.30 & 0.02 & 0.21 \\
\hline Georgia/Armenian & 6.51 & 7.03 & 0.51 & 1.53 \\
\hline Georgia/Azerbaijani & 5.72 & 5.87 & 0.15 & 0.44 \\
\hline
\end{tabular}

Notes: The table columns show mean happiness levels for HW - housewives and WK - working women. Diff: WK-HW reports the difference in mean happiness levels between working women and housewives. t-stats are for the test of mean difference in happiness levels between working women and housewives, within each country. $* * *, * *$, and $*$ indicate significance at 1,5 and $10 \%$ respectively.

Georgian women appear to be the happiest among all the ethnicities, followed by women of Armenian ethnicity, while women of Azerbaijani ethnicity report the lowest level of happiness on average. This ranking holds across the country borders, and for women of all three ethnicities residing within Georgia. This ranking is very consistent with the way the three countries compare across the dimensions discussed in the background section. Less egalitarian views, an unfavorable labor market with higher gender discrimination and limited opportunities to work part-time, and a lack of quality childcare options seem to be associated with lower happiness among women across the three countries.

Next, we focus on the gap in happiness level across the two categories of women. This gap is the largest in Armenia, where working women are significantly less happy than housewives. The situation in Azerbaijan is similar, but the differences in happiness levels across the two groups are smaller. Instead, working women in Georgia appear to be mildly happier compared to housewives in the country. The levels of happiness of women of Armenian and Azerbaijani ethnicity living in Georgia are below that of women of Georgian ethnicity. Interestingly, within the groups of ethnic minorities residing in Georgia, we do not observe lower happiness for working women versus 
housewives, like we do in Armenia and Azerbaijan. So, at least at this stage, the negative happiness gap due to employment seems to be more of a country effect than being due to ethnicity/culture.

One problem that we have when dealing with self-rated measures of happiness on the scale from 1 to 10 is the tendency of people who feel at a level corresponding to the mid-ranges of values to choose the central option(s) as their response. That leads to a clustering of answers at the central values of the variable range, which results an alteration of the distribution of true feelings, leading to biases in statistics based on reported values. Graph A1 in the Appendix confirms our concern about the clustering of values in the middle of the variable range for happiness measures. The high frequency of these "middle" responses makes the average values of happiness closer to those values for both employed women and housewives, making it harder to detect differences in the averages across the two groups.

Taking this issue into consideration, we complement our analysis by looking at the tails of the happiness distribution, defining two new outcomes of interest: very happy (combining the values 8 , 9 , and 10) and very unhappy (combining the values 1,2 , and 3 ).

Table 8 reports the proportions of women reporting to be very happy or very unhappy for each country and within Georgia - for each ethnicity. We find a large negative gap in being very happy between working women and housewives in Armenia and Azerbaijan - working women in these countries are significantly less likely to achieve the highest levels of happiness. In addition, working women in Azerbaijan are more likely to report being very unhappy compared to housewives in the country. In comparison, in Georgia working women are significantly more likely to report being very happy and less likely to report being very unhappy compared to housewives in Georgia.

Table 8: Proportion of very happy or very unhappy women, by country and working status

\begin{tabular}{|c|c|c|c|c|c|}
\hline \multicolumn{2}{|r|}{ Country/Ethnicity } & HW & WK & Diff: WK-HW & t-stat \\
\hline \multirow{6}{*}{ 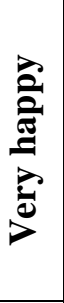 } & Armenia & 0.49 & 0.40 & $-0.09 * * *$ & -4.89 \\
\hline & Azerbaijan & 0.34 & 0.27 & $-0.07 * * *$ & -4.18 \\
\hline & Georgia & 0.46 & 0.49 & $0.03 *$ & 1.76 \\
\hline & Georgia/Georgian & 0.51 & 0.50 & -0.01 & -0.23 \\
\hline & Georgia/Armenian & 0.36 & 0.46 & 0.11 & 1.51 \\
\hline & Georgia/Azerbaijani & 0.22 & 0.19 & -0.03 & -0.49 \\
\hline \multirow{6}{*}{ 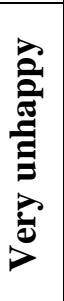 } & Armenia & 0.08 & 0.09 & 0.01 & 0.85 \\
\hline & Azerbaijan & 0.08 & 0.10 & $0.02 * *$ & 2.04 \\
\hline & Georgia & 0.07 & 0.04 & $-0.03 * * *$ & -3.47 \\
\hline & Georgia/Georgian & 0.06 & 0.04 & $-0.02 * *$ & -2.06 \\
\hline & Georgia/Armenian & 0.11 & 0.09 & -0.03 & -0.63 \\
\hline & Georgia/Azerbaijani & 0.12 & 0.06 & -0.05 & -1.17 \\
\hline
\end{tabular}

Note: The table shows proportions of women reporting to be very happy or very unhappy for HW - housewives and WK - working women. Diff: WK-HW reports difference in those proportions for working women and housewives and $\mathrm{t}$-stats are for the test of this difference for each country/ethnicity. $* * *, * *$, and $*$ indicate significance at 1,5 and $10 \%$ respectively. 
Looking at ethnicities within Georgia, most coefficients are small and statistically insignificant, indicating that for the different ethnicities residing in Georgia, there is no difference in the probability of being very happy or very unhappy across working women and housewives.

To summarize, the patterns described in Tables 7 and 8 indicate that in Armenia and Azerbaijan there is a significant negative gap in happiness between working women and housewives, while this gap is positive for the case of Georgia. We do not find a negative happiness gap among Armenian and Azerbaijani minorities residing in Georgia.

Our analysis so far does not capture the fact that women who end up working are different from housewives - a fact that could partially account for the observed differences in happiness levels across working women and housewives. Below we explore how the various factors and characteristics of women contribute to the probability of working versus being housewives in each country/case. We use this information to match women across categories of interest and to check if there is any difference in the outcome variables for comparable women in each given country/case. The "Propensity Score Estimation Details" subsection of the Appendix provides a detailed description of the method behind the results discussed below.

To estimate the probability of working, we apply a probit model estimation where the dependent variable is a binary variable $=1$ if a woman is working and $=0$ if she is a housewife. The selection of explanatory variables for this model is based on several criteria, including variables suggested in literature on this topic, data availability, and the satisfaction of the balancing property required for propensity score matching. The variables in the model are grouped into the following categories:

- Demographic/health characteristics

- Variables measuring human capital

- Variables capturing satisfaction/desires/beliefs

- Characteristics reflecting the economic conditions of the household

- Variables capturing family structure

- Geographic characteristics

Table A2 in the Appendix offers definitions and measurement details for all of the variables used as controls in our matching exercise, and Table A3 provides probit estimation results from each country/ethnicity. Pseudo- $\mathrm{R}^{2}$ in our probit regressions range from 0.2 to 0.5 , so we achieve reasonable fit. The directions of impacts implied by the coefficient estimates are generally in line with the literature. Tables A4 and A5 provide summary statistics for the variables used in probit models (statistics are limited to the sub-sample of observations used in probit models for each country/ethnicity). 
Based on the probit regression results, we split our sample into blocks within which the balancing property is tested for. All our specifications pass this test. As the final step we match treatment and control observations similarity in their predicted probability of working. For robustness we employ three methods of choosing similar observations: nearest-neighbor, radius and Kernel matching. Tables 9 and 10 report differences in the average outcomes for matched treatment and control observations.

Table 9: Average Effect of Treatment on the Treated (ATT), by country

\begin{tabular}{|c|c|c|c|c|c|}
\hline \multicolumn{2}{|c|}{ Outcome/matching method } & N Treated & N Control & ATT & t-stats \\
\hline \multicolumn{6}{|c|}{ Armenia } \\
\hline \multirow{3}{*}{ Happiness } & Nearest neighbor & 1,267 & 466 & $-0.51 * *$ & -2.400 \\
\hline & Radius & 1,267 & 990 & $-0.41 * * *$ & -3.580 \\
\hline & Kernel & 1,267 & 990 & -0.25 & -1.579 \\
\hline \multirow{3}{*}{$\begin{array}{l}\text { Very } \\
\text { Happy }\end{array}$} & Nearest neighbor & 1,274 & 467 & $-0.08 *$ & -1.849 \\
\hline & Radius & 1,274 & 993 & $-0.09 * * *$ & -4.075 \\
\hline & Kernel & 1,274 & 993 & $-0.07 * *$ & -2.139 \\
\hline \multirow{3}{*}{$\begin{array}{c}\text { Very } \\
\text { Unhappy }\end{array}$} & Nearest neighbor & 1,274 & 467 & 0.03 & 1.271 \\
\hline & Radius & 1,274 & 993 & 0.01 & 0.617 \\
\hline & Kernel & 1,274 & 993 & -0.02 & -0.699 \\
\hline \multicolumn{6}{|c|}{ Azerbaijan } \\
\hline \multirow{3}{*}{ Happiness } & Nearest neighbor & 691 & 287 & 0.03 & 0.101 \\
\hline & Radius & 691 & 1,084 & $-0.24 * *$ & -2.240 \\
\hline & Kernel & 691 & 1,084 & 0.00 & -0.018 \\
\hline \multirow{3}{*}{$\begin{array}{l}\text { Very } \\
\text { Happy }\end{array}$} & Nearest neighbor & 703 & 290 & 0.00 & 0.087 \\
\hline & Radius & 703 & 1,098 & $-0.05^{* *}$ & -2.303 \\
\hline & Kernel & 703 & 1,098 & 0.01 & 0.456 \\
\hline \multirow{3}{*}{$\begin{array}{c}\text { Very } \\
\text { Unhappy }\end{array}$} & Nearest neighbor & 703 & 290 & 0.01 & 0.149 \\
\hline & Radius & 703 & 1,098 & 0.01 & 0.437 \\
\hline & Kernel & 703 & 1,098 & 0.00 & -0.021 \\
\hline \multicolumn{6}{|c|}{ Georgia } \\
\hline \multirow{3}{*}{ Happiness } & Nearest neighbor & 1,019 & 295 & 0.14 & 0.542 \\
\hline & Radius & 1,019 & 583 & 0.08 & 0.567 \\
\hline & Kernel & 1,019 & 583 & 0.12 & 0.484 \\
\hline \multirow{3}{*}{$\begin{array}{l}\text { Very } \\
\text { Happy }\end{array}$} & Nearest neighbor & 1,032 & 299 & 0.01 & 0.239 \\
\hline & Radius & 1,032 & 589 & 0.02 & 0.563 \\
\hline & Kernel & 1,032 & 589 & 0.01 & 0.320 \\
\hline \multirow{3}{*}{$\begin{array}{c}\text { Very } \\
\text { Unhappy }\end{array}$} & Nearest neighbor & 1,032 & 299 & 0.00 & -0.068 \\
\hline & Radius & 1,032 & 589 & -0.01 & -1.028 \\
\hline & Kernel & 1,032 & 589 & 0.00 & 0.052 \\
\hline
\end{tabular}

Note: $* * *, * *$, and $*$ indicate significance at 1,5 and $10 \%$ respectively.

Even after matching, there is a significant negative gap in happiness between working women and housewives in Armenia, and this is mostly due to having a lower probability of working women feeling very happy. 
A large part of the negative gap in Azerbaijan reported earlier seems to be due to the selection of women into working/housewife status, as it decreases after we control for selection. However, controlling for selection does not fully eliminate the gap in Azerbaijan - part of the gap is still there, signaling that on average Azerbaijani working women feel less happy than their housewife counterparts (however, this finding is not very robust across matching methods). Similar to the case of Armenia, this gap in happiness seems to be due to the fact that working women in Azerbaijan are less likely to report being very happy compared to their housewife matches.

Table 10: Average Effect of Treatment on the Treated (ATT) by ethnicity, for Georgia

\begin{tabular}{|c|c|c|c|c|c|}
\hline \multicolumn{2}{|c|}{ Outcome/matching method } & N Treated & N Control & ATT & t-stats \\
\hline \multicolumn{6}{|c|}{ Georgia/Georgian } \\
\hline \multirow{3}{*}{ Happiness } & Nearest neighbor & 922 & 265 & 0.06 & 0.229 \\
\hline & Radius & 922 & 461 & -0.05 & -0.333 \\
\hline & Kernel & 922 & 461 & 0.05 & 0.223 \\
\hline \multirow{3}{*}{$\begin{array}{l}\text { Very } \\
\text { Happy }\end{array}$} & Nearest neighbor & 934 & 269 & -0.01 & -0.226 \\
\hline & Radius & 934 & 464 & -0.01 & -0.370 \\
\hline & Kernel & 934 & 464 & 0.00 & 0.029 \\
\hline \multirow{3}{*}{$\begin{array}{c}\text { Very } \\
\text { Unhappy }\end{array}$} & Nearest neighbor & 934 & 269 & -0.01 & -0.292 \\
\hline & Radius & 934 & 464 & -0.01 & -0.438 \\
\hline & Kernel & 934 & 464 & 0.01 & 0.534 \\
\hline \multicolumn{6}{|c|}{ Georgia/Armenian } \\
\hline \multirow{3}{*}{ Happiness } & Nearest neighbor & 50 & 12 & 0.17 & 0.215 \\
\hline & Radius & 46 & 27 & 0.52 & 0.772 \\
\hline & Kernel & 50 & 27 & -0.19 & -0.261 \\
\hline \multirow{3}{*}{$\begin{array}{l}\text { Very } \\
\text { Happy }\end{array}$} & Nearest neighbor & 51 & 12 & 0.19 & 1.201 \\
\hline & Radius & 47 & 28 & 0.15 & 1.140 \\
\hline & Kernel & 51 & 28 & -0.11 & -0.503 \\
\hline \multirow{3}{*}{$\begin{array}{c}\text { Very } \\
\text { Unhappy }\end{array}$} & Nearest neighbor & 51 & 12 & 0.10 & 0.628 \\
\hline & Radius & 47 & 28 & -0.03 & -0.332 \\
\hline & Kernel & 51 & 28 & 0.06 & 0.850 \\
\hline \multicolumn{6}{|c|}{ Georgia/Azerbaijani } \\
\hline \multirow{3}{*}{ Happiness } & Nearest neighbor & 42 & 22 & $1.68 * * *$ & 2.985 \\
\hline & Radius & 41 & 51 & $1.27 * * *$ & 3.435 \\
\hline & Kernel & 42 & 51 & $1.70 * * *$ & 2.935 \\
\hline \multirow{3}{*}{$\begin{array}{l}\text { Very } \\
\text { Happy }\end{array}$} & Nearest neighbor & 43 & 22 & 0.07 & 0.906 \\
\hline & Radius & 42 & 52 & 0.09 & 1.400 \\
\hline & Kernel & 43 & 52 & 0.11 & 1.485 \\
\hline \multirow{3}{*}{$\begin{array}{c}\text { Very } \\
\text { Unhappy }\end{array}$} & Nearest neighbor & 43 & 22 & $-0.36 * * *$ & -2.857 \\
\hline & Radius & 42 & 52 & $-0.21 * * *$ & -3.193 \\
\hline & Kernel & 43 & 52 & $-0.29 * * *$ & -2.719 \\
\hline
\end{tabular}

Note: $* * * * *$, and $*$ indicate significance at 1,5 and $10 \%$ respectively. 
After our matching exercise, all earlier observed differences for Georgia disappear: there seems to be no significant negative gap in happiness levels when comparing similar working women and housewives residing in Georgia, including those of ethnic minorities (if anything, we observe a positive happiness gap in happiness for working Azerbaijani women living in Georgia compared to their housewife matches, and the result is mostly driven by a lower probability of being "very unhappy").

We perform several checks to assess the robustness of our main findings (the results are not reported in this paper $\left.^{6}\right)$. In particular, we re-run the analysis using:

- Alternative classification of women into housewives and working women. Specifically, we classify as "housewives" as all women reporting to be ("Housewife and not working" and "Not employed") and ("Not currently looking for jobs") instead of ("Not being interested in a job"). This alternative classification follows a stricter definition of unemployment.

- Comparison of housewives and women in the labor force (grouping working women and unemployed together).

- Alternative specifications of the probit regressions used in the matching process.

- Self-reported level of life satisfaction instead of happiness.

We find some differences in the magnitudes and significance of results across these various alternative estimations; however, the main findings reported in our paper remain: there is strong evidence that the wellbeing of working women in Armenia is below that of the housewives, the same conclusion holds (albeit to a weaker extent) for the case of Azerbaijan, while there is no negative gap in wellbeing in the case of Georgia (overall, and across minorities).

\section{Conclusion}

We conduct a comparative analysis of happiness of working women and housewives in the three countries of the South Caucasus using a matching technique. Our findings indicate that there are some differences in the way women feel given their employment status. In particular, we find a significant negative happiness gap for working women in Armenia and a smaller negative gap for working women in Azerbaijan compared to their housewife counterparts. No such effect is observed for women residing in Georgia - the country that is the closest among the three South Caucasus countries to the values, labor market outcomes and childcare statistics of EU countries.

When checking for differences in extreme responses, we find a significantly lower probability of being very happy among Armenian working women compared to their housewife matches. A similar, but weaker in magnitude and significance, phenomenon is observed in Azerbaijan. In

${ }^{6}$ The results of alternative specifications are available upon request. 
Georgia the tails of the happiness distributions for working women of all ethnicities and comparable housewives are not significantly different.

A separate analysis of women of Armenian and Azerbaijani ethnicity living in Georgia shows that there is no negative effect from being employed within these groups. This makes us believe that the negative happiness gap that we find in Armenia and Azerbaijan is more of a country-specific effect, rather than a cultural/ethnic factor. Our discussion in the background section contains candidates for the factors behind these country effects. Better pre-school care options and a more favorable labor market for women in Georgia might help women in that country to minimize the stress of combining household duties with work and not sacrifice their happiness and life satisfaction. Further research in this direction can help shed light on the true nature of the relationship between the availability of pre-school care, part-time work and lower gender discrimination on the well-being of working women and housewives. 


\section{References}

Allen, T. D., Herst, D. E., Bruck, C. S., \& Sutton, M. (2000). "Consequences Associated with Workto-Family Conflict: A Review and Agenda for Future Research." Journal of Occupational Health Psychology, 5(2), 278-308.

Alonso-Borrego, C., \& Carrasco, R. (2017). "Employment and the risk of domestic violence: does the breadwinner's gender matter?" Applied Economics, 49(50), 5074-5091.

Ball, R., \& Chernova, K. (2008). "Absolute Income, Relative Income, and Happiness." Social Indicators Research, 88(3), 497-529.

Baxter, J., \& Tai , T.-O. (2016). Inequalities in Unpaid Work: A Cross-National Comparison. In M. L. Connerley, \& J. Wu, Handbook on Well-Being of Working Women. Dordrecht: Springer.

Beblo, M., \& Beninger, D. (2017, September ). "Do husbands and wives pool their incomes? A couple experiment." Review of Economics of the Household, 15(3), 779-805.

Behtoui, A. (2007). "The Distribution and Return of Social Capital: Evidence from Sweden." European Societies, 9(3), 383-407.

Beja, E. (2012). "Who is happier:the housewife or working wife?" Munich Personal RePEc Archive Paper.

Blanchflower, D., \& Oswald, A. (1998). "What makes an entrepreneur." Journal of Labor Economics, 16(1), 26-60.

Blau, F. D., Ferber, M. A., \& Winkler, A. (2006). The Economics of Women, Men and Work. Pearson.

Bohnke, P. (2005). First European Quality of Life Survey: Life Satisfaction, Happiness and Sense of Belonging. Luxembourg: Office for Official Publications of the European Communities.

Booth, A. L., \& Ours, J. C. (2008). "Job satisfaction and family happiness: the part-time work puzzle." Economic Journal, 118(526), F77-F99.

Booth, A. L., \& Ours, J. C. (2009). "Hours of work and gender identity: Does part-time work make the family happier?" Economica, 76(301), 176-196.

Booth, A., \& Ours, J. v. (2010). "Part-time jobs: What women want?" Discussion Paper No. 4686.

Brodeur, A., \& Connolly , M. (2012). "Do Higher Childcare Subsidies Improve Parental Wellbeing? Evidence from Québec's Family Policies." IZA Discussion Paper Series 6804.

Campbell, A. (1981). The Sense of Well-Being in America: Recent Patterns and Trends. McGraw Hill.

Charles, M., \& Cech, E. (2010). "Cross-National Beliefs about Maternal Employment. In J. Treas, \& S. Drobnič, Dividing the Domestic: Men, Women, and Housework in Cross-National Perspective (pp. 147-74)." Stanford University Press.

Crompton, R., \& Lyonette, C. (2005). "The New Gender Essentialism: Domestic and Family 'Choices' and Their Relation to Attitudes." British Journal of Sociology, 56(4), 601-620. 
Dasgupta, U., \& Mani, S. (2015, March). "Only Mine or All Ours: Do Stronger Entitlements Affect Altruistic Choices in the Household." World Development, 67, 363-375.

Easterlin, R. A. (1973). "Does Money Buy Happiness?" Public Interest, 30, 3-10.

England, P., \& Farkas, G. (1986). Households, Employment, and Gender: A Social, Economic, and Demographic View. University of Chicago Press.

Graham, C. (2005). "The economics of happiness-insights on globalization from a novel approach." World Economics, , 6(3), 41-53.

Greenhaus, J. H., \& Powell, G. (2006). "When Work and Family Are Allies: A Theory of WorkFamily Enrichment." Academy of Management Review, 31(1), 72-92.

Guendouzi, J. (2006). "'The Guilt Thing:' Balancing Domestic and Professional Roles." Journal of Marriage and Family, 68(4), 900-909.

Hochschild, A. (1989). The second shift: Working parents and revolution at home. Penguin Books USA Inc.

Hori, M., \& Kamo, Y. (2017). "Gender Differences in Happiness: the Effects of Marriage, Social Roles, and Social Support in East Asia." Applied Research Quality Life, 12(3).

Khitarishvili, T. (2013). "The economic crisis of 2008 and the added worker effect in transition countries." Working Paper 765.

Kuperberg, A., \& Stone, P. (2008). "The Media Depiction of Women Who Opt Out." Gender \& Society, 22(4), 497-517.

Lenze, J., \& Klasen, S. (2017). "Does women's labor force participation reduce domestic violence?" Evidence from Jordan. Feminist Economics.

Lippe, T. v., \& Peters, P. (2007). Competing Claims in Work and Family Life. Edward Elgar Publishing.

Lucas, R. E., Clarke, A. E., Georgellis, Y., \& Diener, E. (2004). "Unemployment Alters the SetPoint for Life Satisfaction." Psychological Science, 15(1), 8-13.

Majlesi, K. (2016). "Labor market opportunities and women's decision making power within households." Journal of Development Economics.

Mencarini, L., \& Vignoli, D. (2018). "Employed Women and Marital Union Stability: It Helps When Men Help." Journal of Family Issues, 39(5).

Mentzakis, E., \& Moro, M. (2009). "The Poor, the Rich and the Happy: Exploring the Link between Income and Subjective Well-Being." Journal of Socio-Economics, 38(1), 147-158.

Mueller, C. W., \& Kim, S.-W. (2008). "The Contented Female Worker: Still a Paradox?" Advances in Group Processes, 25, 117-149.

Nathawat, S., \& Mathur, A. (1992). "Marital adjustment and subjective well-being in Indianeducated housewives and working women." Journal of Psychology, 127(3), 353-358.

Nomaguchi, K. M., Milkie, M. A., \& Bianchi, S. (2005). "Time Strains and Psychological Wellbeing: Do Dual-Earner Mothers and Fathers Differ?" Journal of Family Issues, 26(6), 756792. 
Oduro, A., Deere, C., \& Catanzarite, Z. (2015). "Women's Wealth and Intimate Partner Violence: Insights from Ecuador and Ghana." Feminist Economics, 21(2), 1-29.

Pastore, F., \& Verashchagina, A. (2011). "When does transition increase the gender wage gap? An application to Belarus." Economics of Transition and Institutional Change, 19(2), 333-369.

Rogers, S. J., \& DeBoer, D. (2001). "Changes in Wives' Income: Effects on Marital Happiness, Psychological Well-Being, and the Risk of Divorce." Journal of Marriage and the Family, 63(2), 458-472.

Schoen, R., Rogers, S. J., \& Amato, P. R. (2006). "Wives 'Employment and Spouses' Marital Happiness: Assessing the Direction of Influence Using Longitudinal Couple Data." Journal of Family Issues, 27(4), 506-528.

Stevens, D. P., Minnotte, K. L., Mannon, S. E., \& Kiger, G. (2007). "Examining the "Neglected Side of the Work-Family Interface": Antecedents of Positive and Negative Family-to-Work Spillover." Journal of Family Issues, 28(2), 242-62.

Stevenson, B., \& Wolfers, J. (2009). "The Paradox of Declining Female Happiness." American Economic Journal: Economic Policy, 1(2), 190-225.

Tesch-Römer, C., Motel-Klingebiel, A., \& Tomasik, M. J. (2008). "Gender Differences in Subjective Well-Being: Comparing Societies with Respect to Gender Equality." Social Indicators Research, 85(2), 329-349.

Torosyan, K., Gerber, T. P., \& Gonalons-Pons, P. (2015). "Migration, household tasks, and gender: evidence from the republic of Georgia." International Migration Review, 1-30.

Treas, J., \& Widmer, E. (2000). "Married Women's Employment over the Life Course: Attitudes in Cross-National Perspective." Social Forces, 78(4), 1409-1436.

Treas, J., Lippe, T. v., \& Tai, T.-o. (2011). "The happy homemaker? Married women's well-being in cross-national perspective." Social Forces, 90(1), 111-132.

World Bank. (2011). World Development Report 2012:Gender Equality and Development. Washington D.C.: The International Bank for Reconstruction and Development / The World Bank. 


\section{Appendix}

\section{Propensity Score Estimation Details}

In this section, we briefly discuss the technical details behind the propensity score matching technique and its application in our paper.

Let $e m=\{0,1\}$ be our "treatment" variable, where $e m=1$ if a woman is employed, $e m=0$ otherwise (she is a housewife). Then the conditional probability of being employed, given pre-treatment characteristics of the woman $(\mathbf{X})$ is:

$$
P(\mathbf{X})=\operatorname{Pr}(e m=1 \mid \mathbf{X})=E(e m \mid \mathbf{X})
$$

Rosenbaum and Bubin (1983) show that if the treatment ( $\mathrm{em}=1$ in our case) is random within blocks defined by $\mathbf{X}$ (and as a result, by $\mathrm{P}(\mathbf{X})$ ), then the Average effect of Treatment on the Treated (ATT) can be expressed as follows:

$$
\begin{aligned}
& A T T=E\left(Y_{1 i} \quad Y_{0 i} \mid e m_{i}=1\right)= \\
& =E\left(\left(E\left\{Y_{1 i} \mid e m_{i}=1, P\left(\mathbf{X}_{i}\right)\right\} \quad E\left\{Y_{0 i} \mid e m_{i}=0, P\left(\mathbf{X}_{i}\right)\right\}\right) \mid e m_{i}=1\right)
\end{aligned}
$$

where the outer expectation is with respect to the distribution of $\left\{\mathrm{P}\left(\mathbf{X}_{\mathrm{i}}\right) \mid \mathrm{em}_{\mathrm{i}}=1\right\}$ and $\mathrm{Y}_{1 \mathrm{i}}$ and $\mathrm{Y}_{0 \mathrm{i}}$ are the outcomes of variable of interest in two counterfactual scenarios (if woman $i$ is employed versus if she was a housewife).

This results hinges on the following two conditions:

Condition 1: Balancing of pre-treatment variables given the propensity score $\mathrm{P}(\mathbf{X})$, or

$$
\text { em } \perp \boldsymbol{X} \mid \mathrm{P}(\boldsymbol{X})
$$

Basically, this condition requires that observations with the same propensity score have the same distribution of observable (and unobservable) characteristics independently of treatment status.

Condition 2: Unconfoundedness given the propensity score. If assignment to treatment is unconfounded given pre-treatment information:

$$
Y_{1}, Y_{0} \perp \text { em } \mid \boldsymbol{X}
$$

then it will be also unconfounded given the propensity score:

$$
Y_{1}, Y_{0} \perp e m \mid P(X)
$$

The procedure for matching works in the following way:

- We use a probit model to estimate $P(\mathbf{X})=\operatorname{Pr}($ em $=1 \mid \mathbf{X})$, and based on the results we predict the propensity score for each observation: $\hat{P}(\boldsymbol{X})$. 
- Based on values of $\hat{P}(\boldsymbol{X})$ we split the sample into equally spaced blocks, such that within each block the average of the propensity score is the same (statistically) for treated and control units.

- Within each block we test that the means of each and every characteristic in $\mathbf{X}$ do not differ (statistically) between treatment and control units (this is necessary for the Balancing condition to be in place).

- We match our treated (employed) and control (housewives). As a matching method we use three alternatives: nearest neighbor (where the control observation with the closest value of predicted probability is selected as a match), radius (where all control units with a predicted probability of being employed fall within a given radius from a given treatment observation) and Kernel matching based on Epanechnikov kernel and a default bandwidth of 0.06 (in this method all control observations are used as a match, but are weighted according to the distance in their predicted probabilities from the predicted probability of a given treatment observation).

- Given the matching mechanism, we compute the differences in outcomes between treatment and matched control observations, and take the average of these differences (ATT). In the case of the nearest neighbor and radius matching, analytical standard errors are computed. In the case of Kernel matching, standard errors are bootstrapped (using 100 repetitions). 
Data Notes and Additional Results

Table A1: Country groups based on World Values Survey data

\begin{tabular}{|l|l|}
\hline \multicolumn{1}{|c|}{ FSU countries } & \multicolumn{1}{c|}{ EU countries } \\
\hline Belarus & Netherlands \\
\hline Ukraine & Slovenia \\
\hline Kyrgyzstan & Romania \\
\hline Russian Federation & Poland \\
\hline Kazakhstan & Estonia \\
\hline Uzbekistan & Spain \\
\hline & Germany \\
\hline & Cyprus \\
\hline & Sweden \\
\hline
\end{tabular}

Graph A1: Histogram of self-reported happiness level by country/ethnicity
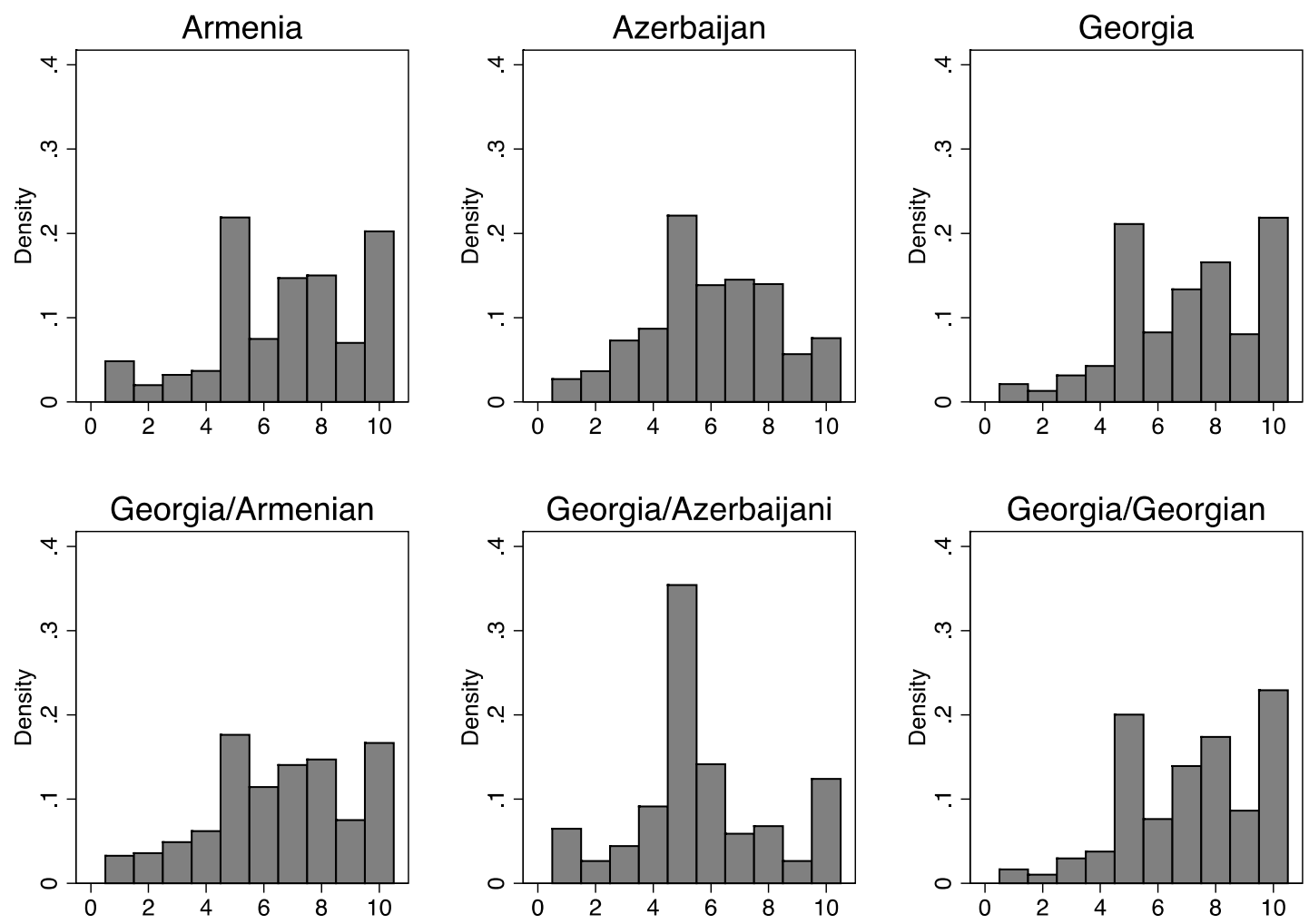

Note: The histograms are based on all observations for women in the 18-60 age range, combining available CB data for 2010-2017 together. 
Table A2: Definition of variables used for matching

\begin{tabular}{|c|c|}
\hline Variable & Definition/range \\
\hline \multicolumn{2}{|r|}{ Demographic/health } \\
\hline Age & Respondent's age $[18 ; 60]$ \\
\hline Single & 1 if respondent is single; 0 - otherwise \\
\hline Married & 1 if respondent is married; 0 - otherwise \\
\hline Armenian & 1 if respondent is of Armenian ethnicity; 0- otherwise \\
\hline Azerbaijani & 1 if respondent is of Azerbaijani ethnicity; 0- otherwise \\
\hline Health rating & Self-reported health rating ( $1=$ extremely poor to $5=$ very good) \\
\hline H1 & 1 if health rating is extremely poor; 0 - otherwise \\
\hline H3 & 1 if health rating is fair; 0 - otherwise \\
\hline H4 & 1 if health rating is good; 0 - otherwise \\
\hline H5 & 1 if health rating is very good; 0 - otherwise \\
\hline \multicolumn{2}{|r|}{ Human capital } \\
\hline Years of educ. & Years of formal education the woman has completed \\
\hline Level of Eng. & Knowledge of English (1=no knowledge to 4=advanced knowledge) \\
\hline Level of Rus. & Knowledge of Russian (1=no knowledge to 4=advanced knowledge) \\
\hline Russian & 1 for intermediate/advanced knowledge of Russian; 0- otherwise \\
\hline \multicolumn{2}{|r|}{ Satisfaction/desires/beliefs } \\
\hline Life satisfaction & Overall life satisfaction $(0=$ not satisfied at all, $10=$ completely satisfied $)$ \\
\hline Desire to migrate & 1 if wants to migrate permanently; 0-oterwise \\
\hline Level of relig. & How religious are you? ( $0=$ not at all religious, $10=$ very religious $)$ \\
\hline RELvery & 1 if considers religion very important in daily life; 0-otherwise \\
\hline RELrath & 1 if considers religion rather important in daily life; 0-otherwise \\
\hline Attend. rel. serv. & Frequency of attending religious services ( $1=$ every day to $7=$ never) \\
\hline RELwk & 1 if attends religious services weekly; 0 - otherwise \\
\hline RELmo & 1 if attends religious services monthly; 0- otherwise \\
\hline RELoc & 1 if attends religious services only occasionally; 0 - otherwise \\
\hline Freq. of fasting & Frequency of fasting when required by religion ( $1=$ always to $5=$ never $)$ \\
\hline FASTof & $=1$ if often/always fasts for religious purposes \\
\hline \multicolumn{2}{|r|}{ Economic condition } \\
\hline Rel. ec. cond. & Perceived relative economic condition (1=very poor to 5=very good) \\
\hline HH econ. Sit. & HH economic situation ( $1=$ not enough money for food, $5=$ enough money for all needs) \\
\hline Enough1 & 1 if not enough money for food; 0-otherwise \\
\hline Enough2 & 1 if not enough money food, but not clothes; 0-otherwise \\
\hline Enough4 & 1 if can afford buying some durables; 0-otherwise \\
\hline HH inc. last mo. & HH monetary income last month $(1=$ more than 1200 USD to $8=$ none $)$ \\
\hline Current ec. rung & Current perceived economic rung (1=lowest to $10=$ highest $)$ \\
\hline N emp. Adults & Number of additional employed adults (not counting the woman herself) \\
\hline \multicolumn{2}{|r|}{ Family structure } \\
\hline N kids $[0 ; 2]$ y.o. & Number of own kids $[0 ; 2]$ years old who live in the $\mathrm{HH}$ \\
\hline N kids $[3 ; 5]$ y.o. & Number of own kids $[3 ; 5]$ years old who live in the $\mathrm{HH}$ \\
\hline N kids $[6 ; 10]$ y.o. & Number of own kids $[6 ; 10]$ years old who live in the HH \\
\hline Grandmother in & 1 if mother(-in-law) of the woman lives in the $\mathrm{HH}, 0$-otherwise \\
\hline Grandfather in & 1 if father(-in-law) of the woman lives in the $\mathrm{HH}, 0$-otherwise \\
\hline $\mathrm{N}$ adults in $\mathrm{HH}$ & Number of additional adults in the HH (not counting the woman herself) \\
\hline Relatives abroad & 1 if a woman has family member currently living abroad, =0 otherwise \\
\hline HH size & Size of the HH \\
\hline
\end{tabular}




\begin{tabular}{|l|l|}
\hline \multicolumn{1}{|c|}{ Variable } & \multicolumn{1}{c|}{ Geographic characteristics } \\
\hline Rural & 1 if from a rural area; 0-otherwise \\
\hline Urban & 1 if from urban area (but not the capital); 0-otherwise \\
\hline NE rural & 1 if from rural North-Eastern part of the country, 0 - otherwise \\
\hline NW rural & 1 if from rural North-Western part of the country, 0- otherwise \\
\hline SE rural & 1 if from rural South-Eastern part of the country, 0 -otherwise \\
\hline SW rural & 1 if from rural South-Western part of the country, 0 - otherwise \\
\hline NE urban & 1 if from urban North-Eastern part of the country, 0 - otherwise \\
\hline NW urban & 1 if from urban North-Western part of the country, 0 - otherwise \\
\hline SE urban & 1 if from urban South-Eastern part of the country, 0 - otherwise \\
\hline SW urban & 1 if from urban South-Western part of the country, 0 - otherwise \\
\hline
\end{tabular}

Notes: Definitions in this table either follow the formulation of questions in the Caucasus Barometer questionnaire (when we use survey variables in their original form), or they reflect the nature of variables that were built based on various survey questions.

Table A3: Results from the Probit regression used for matching

\begin{tabular}{|c|c|c|c|c|c|c|}
\hline Variable & $\mathbf{A R}$ & $\mathbf{A Z}$ & GEO & GEO/GEO & GEO/AR & GEO/AZ \\
\hline \multicolumn{7}{|c|}{ Demographic/health } \\
\hline Age & $0.01 * * *$ & & $0.19 * * *$ & $0.20 * * *$ & $0.04 * *$ & $0.04 * * *$ \\
\hline Single & $0.25 *$ & & $0.51 * * *$ & $0.58 * * *$ & & \\
\hline Married & $-0.59 * * *$ & $-0.84 * * *$ & $-0.51 * * *$ & $-0.50 * * *$ & $-1.21 * * *$ & $-0.73 * *$ \\
\hline Armenian & & & -0.09 & & & \\
\hline Azerbaijani & & & -0.22 & & & \\
\hline Health rating & & & & & $-0.45^{*}$ & \\
\hline H1 & & & $-0.49 *$ & -0.35 & & \\
\hline H3 & & & 0.03 & 0.15 & & \\
\hline H4 & & & 0.06 & $0.26^{*}$ & & \\
\hline H5 & & & 0.15 & 0.24 & & \\
\hline \multicolumn{7}{|c|}{ Human capital } \\
\hline Years of educ. & $0.18 * * *$ & & $0.14 * * *$ & $0.12 * * *$ & $0.27 * * *$ & 0.1 \\
\hline Level of Eng. & $0.07 *$ & & $0.21 * * *$ & $0.19 * * *$ & $0.65^{*}$ & 0.74 \\
\hline Level of Rus. & & & & & $0.67 * *$ & \\
\hline Russian & & $0.29 * * *$ & & & & 0.29 \\
\hline \multicolumn{7}{|c|}{ Satisfaction/desires/beliefs } \\
\hline Life satisfaction & & & $-0.04 *$ & $-0.04 * *$ & & \\
\hline Desire to migrate & $0.14 * *$ & & -0.15 & 0.13 & $-1.08 * * *$ & \\
\hline Level of relig. & & & & & & 0.02 \\
\hline RELvery & $0.20 * * *$ & $-0.30 * * *$ & $0.32 * *$ & $0.37 * *$ & & \\
\hline RELrath & & & 0.18 & 0.17 & & \\
\hline Attend. rel. serv. & & & & & & $-0.31 * *$ \\
\hline RELwk & & & 0.18 & 0.17 & & \\
\hline RELmo & & & 0.22 & 0.21 & & \\
\hline RELoc & & & $0.27 *$ & 0.23 & & \\
\hline Freq. of fasting & & & $0.11 *$ & 0.1 & 0.24 & 0.19 \\
\hline FASTof & & & 0.27 & 0.26 & & \\
\hline
\end{tabular}




\begin{tabular}{|c|c|c|c|c|c|c|}
\hline Variable & $\mathbf{A R}$ & $\mathbf{A Z}$ & GEO & GEO/GEO & GEO/AR & GEO/AZ \\
\hline \multicolumn{7}{|c|}{ Economic condition } \\
\hline Rel. ec. cond. & -0.08 & $0.12 *$ & $0.23 * * *$ & $0.36^{* * *}$ & & \\
\hline HH econ. Sit. & $-0.72 * *$ & & 0 & 0.02 & & \\
\hline Enough1 & $0.82 * * *$ & & & & & \\
\hline Enough2 & $1.57 * * *$ & & & & & \\
\hline Enough4 & $2.12 * *$ & & & & & \\
\hline HH inc. last mo. & $-0.20 * * *$ & $-0.19 * * *$ & $-0.11 * * *$ & $-0.10 * *$ & $-0.33 * *$ & 0.17 \\
\hline Current ec. rung & & $-0.10 * * *$ & $-0.05^{*}$ & $-0.09 * * *$ & & 0.11 \\
\hline N emp. Adults & & $-0.14 * *$ & -0.02 & -0.05 & & \\
\hline \multicolumn{7}{|c|}{ Family structure } \\
\hline N kids $[0 ; 2]$ y.o. & $-0.49 * * *$ & $-0.29 * *$ & $-0.55 * * *$ & $-0.55 * * *$ & & \\
\hline N kids $[3 ; 5]$ y.o. & $-0.18^{* *}$ & 0.01 & -0.01 & -0.01 & & \\
\hline N kids $[6 ; 10]$ y.o. & $-0.23 * * *$ & $-0.15^{*}$ & -0.11 & $-0.16^{*}$ & & \\
\hline Grandmother in & $0.23 * * *$ & $0.30 * * *$ & & & & \\
\hline Grandfather in & & -0.12 & & & & \\
\hline $\mathrm{N}$ adults in $\mathrm{HH}$ & $-0.05^{*}$ & & & & & \\
\hline Relatives abroad & & & -0.06 & -0.03 & $0.85 * *$ & \\
\hline HH size & & $-0.09 * * *$ & & & & -0.08 \\
\hline \multicolumn{7}{|c|}{ Geographic characteristics } \\
\hline Rural & & $0.21 *$ & & & & \\
\hline Urban & & $0.20 * *$ & $0.42 * * *$ & $0.63 * * *$ & 0.37 & \\
\hline NE urban & & & 0.01 & -0.15 & & \\
\hline NE rural & & & $0.41 * * *$ & $0.38^{* * * *}$ & & \\
\hline NW rural & $0.35 * * *$ & $-0.51 * * *$ & 0.03 & 0.01 & & \\
\hline SE urban & & & -0.1 & -0.23 & & \\
\hline SE rural & & & $0.33^{* *}$ & $0.37 * *$ & & \\
\hline SW urban & & & -0.14 & $-0.41 * *$ & & \\
\hline SW rural & & & -0.18 & -0.17 & & \\
\hline $\mathbf{N}$ & 2286 & 1811 & 1644 & 1425 & 107 & 117 \\
\hline Pseudo-R2 & 0.21 & 0.3 & 0.23 & 0.23 & 0.52 & 0.28 \\
\hline
\end{tabular}

Notes: The results are from probit regressions where the dependent variable is $=1$ for working women and $=0$ for housewives. The unit of observation is each woman of working age (18-60 years old). The columns report the results for: Arm - women residing in Armenia; Az - women residing in Azerbaijan; Geo - women residing in Georgia; Geo/Geo - women of Georgian ethnicity residing in Georgia; Geo/Arm - women of Armenian ethnicity residing in Georgia; Geo/Az - women of Azerbaijani ethnicity residing in Georgia. The table reports probit regression coefficients, ${ }^{* * *}, * *$, and $*$ indicate significance at 1,5 , and $10 \%$ levels. Pseudo-R2 reports McFadden's pseudo- $\mathrm{R}^{2}$. 
Table A4: Summary statistics for variables used for matching, by country

\begin{tabular}{|c|c|c|c|c|c|c|}
\hline \multirow[b]{2}{*}{ Variable } & \multicolumn{2}{|c|}{$\mathbf{A R}$} & \multicolumn{2}{|c|}{$\mathbf{A Z}$} & \multicolumn{2}{|c|}{ GEO } \\
\hline & Mean & St.D & Mean & St.D & Mean & St.D \\
\hline \multicolumn{7}{|c|}{ Demographic/health } \\
\hline Age & 41.4 & 11.6 & 38.4 & 10.8 & 41.7 & 11.4 \\
\hline Single & 0.11 & 0.32 & 0.09 & 0.29 & 0.13 & 0.33 \\
\hline Married & 0.70 & 0.46 & 0.76 & 0.43 & 0.70 & 0.46 \\
\hline Armenian & 0.99 & 0.10 & 0.00 & 0.00 & 0.06 & 0.23 \\
\hline Azerbaijani & 0.00 & 0.00 & 0.95 & 0.22 & 0.06 & 0.23 \\
\hline Health rating & 3.12 & 0.84 & 3.55 & 0.84 & 3.26 & 0.83 \\
\hline H1 & 0.05 & 0.21 & 0.01 & 0.09 & 0.02 & 0.14 \\
\hline H3 & 0.52 & 0.50 & 0.35 & 0.48 & 0.49 & 0.50 \\
\hline H4 & 0.27 & 0.45 & 0.44 & 0.50 & 0.31 & 0.46 \\
\hline H5 & 0.03 & 0.18 & 0.11 & 0.31 & 0.06 & 0.24 \\
\hline \multicolumn{7}{|c|}{ Human capital } \\
\hline Years of educ. & 12.3 & 2.5 & 11.5 & 2.3 & 13.3 & 2.7 \\
\hline Level of Eng. & 1.74 & 0.92 & 1.34 & 0.67 & 1.68 & 0.96 \\
\hline Level of Rus. & 3.03 & 0.70 & 2.10 & 0.99 & 2.94 & 0.90 \\
\hline Russian & 0.83 & 0.38 & 0.35 & 0.48 & 0.74 & 0.44 \\
\hline \multicolumn{7}{|c|}{ Satisfaction/desires/beliefs } \\
\hline Life satisfaction & 5.52 & 2.45 & 5.40 & 2.14 & 5.70 & 2.31 \\
\hline Desire to migrate & 0.26 & 0.44 & 0.12 & 0.33 & 0.07 & 0.25 \\
\hline Level of relig. & 6.94 & 2.61 & 4.82 & 2.32 & 6.79 & 2.19 \\
\hline RELvery & 0.53 & 0.50 & 0.35 & 0.48 & 0.45 & 0.50 \\
\hline RELrath & 0.35 & 0.48 & 0.46 & 0.50 & 0.48 & 0.50 \\
\hline Attend. rel. serv. & 5.03 & 1.29 & 5.55 & 1.19 & 4.65 & 1.32 \\
\hline RELwk & 0.10 & 0.30 & 0.03 & 0.18 & 0.21 & 0.41 \\
\hline RELmo & 0.26 & 0.44 & 0.09 & 0.29 & 0.24 & 0.43 \\
\hline RELoc & 0.45 & 0.50 & 0.61 & 0.49 & 0.48 & 0.50 \\
\hline Freq. of fasting & 4.70 & 0.77 & 3.64 & 1.36 & 3.83 & 1.38 \\
\hline FASTof & 0.03 & 0.17 & 0.20 & 0.40 & 0.21 & 0.40 \\
\hline \multicolumn{7}{|c|}{ Economic conditions } \\
\hline Rel. ec. cond. & 2.98 & 0.64 & 2.83 & 0.76 & 2.83 & 0.64 \\
\hline HH econ. Sit. & 2.21 & 0.94 & 2.46 & 0.95 & 2.34 & 0.95 \\
\hline Enough1 & 0.34 & 0.48 & 0.31 & 0.46 & 0.37 & 0.48 \\
\hline Enough2 & 0.32 & 0.47 & 0.39 & 0.49 & 0.33 & 0.47 \\
\hline Enough4 & 0.07 & 0.25 & 0.11 & 0.32 & 0.09 & 0.29 \\
\hline HH inc. last mo. & 4.60 & 1.26 & 3.71 & 1.17 & 4.77 & 1.38 \\
\hline Current ec. rung & 4.43 & 1.60 & 4.30 & 1.69 & 4.47 & 1.65 \\
\hline N emp. Adults & 0.87 & 0.95 & 0.99 & 0.78 & 0.77 & 0.84 \\
\hline \multicolumn{7}{|c|}{ Family structure } \\
\hline $\mathrm{N}$ kids $[0 ; 2]$ y.o. & 0.07 & 0.27 & 0.10 & 0.32 & 0.08 & 0.29 \\
\hline N kids $[3 ; 5]$ y.o. & 0.13 & 0.37 & 0.17 & 0.44 & 0.11 & 0.36 \\
\hline N kids $[6 ; 10]$ y.o. & 0.20 & 0.49 & 0.26 & 0.57 & 0.18 & 0.47 \\
\hline Grandmother in & 0.29 & 0.45 & 0.27 & 0.44 & 0.29 & 0.45 \\
\hline Grandfather in & 0.16 & 0.37 & 0.19 & 0.39 & 0.16 & 0.37 \\
\hline $\mathrm{N}$ adults in $\mathrm{HH}$ & 1.97 & 1.37 & 2.06 & 1.29 & 1.89 & 1.27 \\
\hline Relatives abroad & 0.78 & 0.42 & 0.47 & 0.50 & 0.53 & 0.50 \\
\hline HH size & 3.89 & 1.84 & 4.11 & 1.65 & 3.68 & 1.66 \\
\hline
\end{tabular}




\begin{tabular}{|l|c|c|c|c|c|c|}
\hline \multirow{2}{*}{ Variable } & \multicolumn{2}{c|}{ AR } & \multicolumn{2}{c|}{ AZ } & \multicolumn{2}{c|}{ GEO } \\
\cline { 2 - 8 } & Mean & St.D & Mean & St.D & Mean & St.D \\
\hline Rural & 0.33 & 0.47 & 0.24 & 0.43 & 0.39 & 0.49 \\
\hline Urban & 0.24 & 0.43 & 0.43 & 0.50 & 0.36 & 0.48 \\
\hline NE rural & 0.09 & 0.28 & 0.05 & 0.21 & 0.14 & 0.34 \\
\hline NW rural & 0.09 & 0.29 & 0.06 & 0.23 & 0.08 & 0.27 \\
\hline SE rural & 0.07 & 0.26 & 0.13 & 0.34 & 0.11 & 0.32 \\
\hline SW rural & 0.07 & 0.26 & 0.01 & 0.09 & 0.06 & 0.24 \\
\hline NE urban & 0.07 & 0.26 & 0.08 & 0.27 & 0.09 & 0.29 \\
\hline NW urban & 0.06 & 0.23 & 0.15 & 0.36 & 0.13 & 0.34 \\
\hline SE urban & 0.07 & 0.25 & 0.12 & 0.32 & 0.07 & 0.25 \\
\hline SW urban & 0.04 & 0.19 & 0.08 & 0.28 & 0.07 & 0.26 \\
\hline N & \multicolumn{7}{|c|}{$\mathbf{2 2 8 6}$} & $\mathbf{1 8 1 1}$ & \multicolumn{1}{c|}{$\mathbf{1 6 4 4}$} \\
\hline
\end{tabular}

Notes: Columns report the mean and standard deviation for each variable for: Arm - women residing in Armenia; Az - women residing in Azerbaijan; Geo - women residing in Georgia; The samples are restricted to observations used in probit regressions reported in Table A3.

Table A5: Summary statistics for variables used for matching by ethnicity within Georgia

\begin{tabular}{|l|c|c|c|c|c|c|}
\hline \multirow{2}{*}{ Variable } & \multicolumn{2}{c}{ GEO/GEO } & \multicolumn{2}{c|}{ GEO/AR } & \multicolumn{2}{c|}{ GEO/AZ } \\
\cline { 2 - 7 } & Mean & St.D & Mean & St.D & Mean & St.D \\
\hline \multicolumn{7}{|c|}{ Demographic/health } \\
\hline Age & 41.7 & 11.3 & 40.9 & 11.4 & 38.7 & 12.9 \\
\hline Single & 0.13 & 0.34 & 0.09 & 0.29 & 0.08 & 0.27 \\
\hline Married & 0.69 & 0.46 & 0.73 & 0.45 & 0.77 & 0.42 \\
\hline Health rating & 3.27 & 0.84 & 3.24 & 0.71 & 3.22 & 0.86 \\
\hline H1 & 0.02 & 0.15 & 0.00 & 0.00 & 0.03 & 0.16 \\
\hline H3 & 0.48 & 0.50 & 0.50 & 0.50 & 0.48 & 0.50 \\
\hline H4 & 0.31 & 0.46 & 0.35 & 0.48 & 0.29 & 0.46 \\
\hline H5 & 0.06 & 0.25 & 0.02 & 0.14 & 0.06 & 0.24 \\
\hline \multicolumn{7}{|c|}{ Human capital } \\
\hline Years of educ. & 13.7 & 2.6 & 11.8 & 2.5 & 10.1 & 2.2 \\
\hline Level of Eng. & 1.73 & 0.98 & 1.55 & 0.90 & 1.10 & 0.40 \\
\hline Level of Rus. & 2.96 & 0.86 & 3.27 & 0.73 & 2.05 & 1.04 \\
\hline Russian & 0.75 & 0.43 & 0.87 & 0.34 & 0.36 & 0.48 \\
\hline \multicolumn{7}{|c|}{ Satisfaction/desires/beliefs } \\
\hline Life satisfaction & 5.81 & 2.31 & 5.50 & 2.04 & 4.70 & 2.28 \\
\hline Desire to migrate & 0.04 & 0.20 & 0.41 & 0.49 & 0.09 & 0.28 \\
\hline Level of relig. & 7.05 & 2.02 & 6.12 & 2.12 & 3.86 & 2.44 \\
\hline RELvery & 0.47 & 0.50 & 0.20 & 0.40 & 0.41 & 0.49 \\
\hline RELrath & 0.48 & 0.50 & 0.59 & 0.49 & 0.38 & 0.49 \\
\hline Attend. rel. serv. & 4.59 & 1.33 & 4.58 & 1.19 & 5.25 & 1.04 \\
\hline RELwk & 0.23 & 0.42 & 0.20 & 0.40 & 0.04 & 0.20 \\
\hline RELmo & 0.25 & 0.43 & 0.32 & 0.47 & 0.05 & 0.22 \\
\hline RELoc & 0.46 & 0.50 & 0.42 & 0.50 & 0.78 & 0.42 \\
\hline Freq. of fasting & 3.80 & 1.41 & 4.11 & 1.00 & 3.95 & 1.27 \\
\hline FASTof & 0.22 & 0.41 & 0.08 & 0.28 & 0.15 & 0.35 \\
\hline
\end{tabular}




\begin{tabular}{|c|c|c|c|c|c|c|}
\hline \multirow[b]{2}{*}{ Variable } & \multicolumn{2}{|c|}{ GEO/GEO } & \multicolumn{2}{|c|}{ GEO/AR } & \multicolumn{2}{|c|}{ GEO/AZ } \\
\hline & Mean & St.D & Mean & St.D & Mean & St.D \\
\hline \multicolumn{7}{|c|}{ Economic conditions } \\
\hline Rel. ec. cond. & 2.83 & 0.64 & 2.88 & 0.61 & 2.77 & 0.79 \\
\hline HH econ. Sit. & 2.35 & 0.98 & 2.36 & 0.75 & 2.25 & 0.76 \\
\hline Enough1 & 0.36 & 0.48 & 0.44 & 0.50 & 0.50 & 0.50 \\
\hline Enough2 & 0.34 & 0.47 & 0.36 & 0.48 & 0.28 & 0.45 \\
\hline Enough4 & 0.10 & 0.30 & 0.05 & 0.21 & 0.05 & 0.22 \\
\hline HH inc. last mo. & 4.69 & 1.38 & 5.17 & 1.34 & 5.56 & 1.14 \\
\hline Current ec. rung & 4.52 & 1.65 & 4.48 & 1.53 & 3.78 & 1.80 \\
\hline N emp. Adults & 0.79 & 0.85 & 0.69 & 0.92 & 0.81 & 0.71 \\
\hline \multicolumn{7}{|c|}{ Family structure } \\
\hline N kids [0;2] y.o. & 0.08 & 0.29 & 0.06 & 0.23 & 0.11 & 0.34 \\
\hline N kids $[3 ; 5]$ y.o. & 0.11 & 0.35 & 0.13 & 0.37 & 0.17 & 0.53 \\
\hline $\mathrm{N}$ kids [6;10] y.o. & 0.17 & 0.46 & 0.22 & 0.56 & 0.22 & 0.54 \\
\hline Grandmother in & 0.28 & 0.45 & 0.36 & 0.48 & 0.36 & 0.48 \\
\hline Grandfather in & 0.17 & 0.37 & 0.20 & 0.40 & 0.22 & 0.42 \\
\hline $\mathrm{N}$ adults in $\mathrm{HH}$ & 1.88 & 1.27 & 2.10 & 1.23 & 2.23 & 1.35 \\
\hline Relatives abroad & 0.49 & 0.50 & 0.75 & 0.44 & 0.82 & 0.39 \\
\hline HH size & 3.67 & 1.65 & 3.97 & 1.64 & 4.03 & 1.88 \\
\hline \multicolumn{7}{|c|}{ Geographic characteristics } \\
\hline Rural & 0.40 & 0.49 & 0.22 & 0.41 & 0.50 & 0.50 \\
\hline Urban & 0.33 & 0.47 & 0.62 & 0.49 & 0.33 & 0.47 \\
\hline NE rural & 0.14 & 0.34 & 0.01 & 0.10 & 0.24 & 0.43 \\
\hline NW rural & 0.09 & 0.29 & 0.00 & 0.00 & 0.01 & 0.09 \\
\hline SE rural & 0.10 & 0.30 & 0.17 & 0.38 & 0.25 & 0.43 \\
\hline SW rural & 0.07 & 0.25 & 0.04 & 0.19 & 0.00 & 0.00 \\
\hline NE urban & 0.10 & 0.30 & 0.01 & 0.10 & 0.00 & 0.00 \\
\hline NW urban & 0.10 & 0.31 & 0.33 & 0.47 & 0.27 & 0.45 \\
\hline SE urban & 0.06 & 0.24 & 0.16 & 0.37 & 0.02 & 0.13 \\
\hline SW urban & 0.07 & 0.25 & 0.12 & 0.33 & 0.04 & 0.20 \\
\hline $\mathbf{N}$ & \multicolumn{2}{|c|}{1425} & \multicolumn{2}{|c|}{107} & \multicolumn{2}{|c|}{117} \\
\hline
\end{tabular}

Notes: Columns report the mean and standard deviation for each variable for: $\mathrm{Geo} / \mathrm{Geo}$ - women of Georgian ethnicity residing in Georgia; Geo/Arm - women of Armenian ethnicity residing in Georgia; Geo/Az - women of Azerbaijani ethnicity residing in Georgia. The samples are restricted to observations used in probit regressions reported in Table A3. 